\title{
MJN QUALITY OF EXPERIENCES (QOE) WITH E-LEARNING AMONG NURSING STUDENTS IN A PRIVATE HEALTHCARE UNIVERSITY SETTING IN MALAYSIA
}

\author{
Annamma Kunjukunju*, Puziah Yusof, Aini Ahmad \\ School of Nursing, KPJ Healthcare University College, Negeri Sembilan, Malaysia \\ *Corresponding Author's Email: ann@ kpjuc.edu.my
}

\begin{abstract}
Background: During the COVID-19 pandemic, students in higher education institutions are not allowed to be on campuses due to safety reasons. However, educational activities need to continue, and students need to graduate on time. To facilitate teaching, learning, and assessment, E-learning had been adopted globally by all educational institutions from schools to Higher learning institutes. Therefore, this research aims to assess nursing students' satisfaction and behavioural intentions towards E-learning, mainly on the Moodle-based Learning Management System (LMS). Methods: This cross-sectional survey study includes 160 nursing students from one of the private nursing colleges in Malaysia. A validated questionnaire SERVQUAL was used for data collection. The questionnaire has five (5) quality dimension constructs to measure E-learning quality. The questionnaire also included questions related to satisfaction with the E-learning and behavioural intentions of learners regarding the use of E-learning in the future. The data was collected using Google forms. Results: The study findings show that respondents positively rated E-learning quality on a Likert scale of $1-4$, ranging from strongly disagree to strongly agree $(\mathrm{M}=2.5 ; \mathrm{SD}=0.36)$. Pearson Correlation test showed that all five quality dimensions, namely "Empathy," "Assurance," "Reliability," "Responsiveness," and web content quality, had positive Correlation with E-learning quality. However, "Reliability" and website content had the most positive influence on E-learning quality $(r=0.733 ; p=0.000)$. The findings also suggest that E-learning quality was not a big driver for the behavioural intentions in promoting online Elearning $(r=0.185 ; p=0.019)$. However, grade expectations were found to have a strong positive relationship with the satisfaction of learners with E-learning. Conclusion: Providing quality E-learning platforms and experiences can help improve the E-learning quality experience of the learners, promote satisfaction and grade expectations of the learners of higher education institutions. Given the characteristics of nursing students, it is necessary to develop and apply an effective and viable E-learning educational program to sustain motivation and produced the desired learning outcome among nursing students.
\end{abstract}

Keywords: E-learning, E-learning; Nursing Sudent; Quality of Experience; E-learning Quality

\section{INTRODUCTION}

There has been an abrupt wave of uncertainty in the education sector, especially in higher education as a result of the COVID 19 Pandemic. This is countered to some extent by the easy availability of Information and communication technology (ICT). However, assessment of E-learning quality is an important measure to evaluate and ensure provision of good quality education. E- learning may be appealing to students because of convenience to use anytime, anywhere, according to personal preferences (Doherty, 2006).

\section{Background of the Study}

Malaysia temporarily closed all educational institutes on $17^{\text {th }}$ March 2020 and switched all educational activities to E-learning during the Movement Control Order (MCO) 
period related to COVID 19 pandemic containment. Schools and universities have thus organized all teaching and learning activities via distance E-learning using various E-learning platforms. E-learning is now mandatory to all the students regardless of userfriendliness access to gadgets or the internet or student's motivation to learn online or preference to E-learning. Conversely, teachers also have numerous issues in swiftly transferring to E-learning mode and preparing teaching learning and assessment materials in online platforms. Most importantly, technical issues like teachers' Information and Communication Technology (ICT) skills in handling synchronized and asynchronized educational platforms are crucial. The quality of Elearning resources is indirectly proportional to the motivation of students in using E-learning as a learning strategy. Altogether the quality of Experience with Elearning is decided by the knowledge or subject expertise of the teachers, which is the deciding factor for "Reliability" and "Responsiveness." Another major factor is the commitment or "Assurance" of the teachers in using E-learning platforms to make the E-learning experience meaningful to students. With the availability of various social media platforms, some teachers who are not comfortable with the Moodle-based Learning Management System (LMS) switched to the use of media like Telegram or even WhatsApp for exchanging information with students.

Globally, the educational sector is accepting the norm of "learning and training anywhere anytime" (Aggarwal \& Comyn, 2020). Teachers and students have been equally challenged in the sudden requisite to switch to E-learning. This study is mainly aimed to assess the Quality of Experience with E-learning using different quality dimensions presented in the SERVQUAL questionnaire.

\section{Purpose of the Study}

To investigate nursing students' (1) perception towards E-learning quality dimensions (2) E-learning quality (3) behavioural intentions towards E-learning (4) satisfaction with E-learning and (5) students grade expectations related to Moodle-based Learning Management System (LMS) during the COVID -19 pandemic.

\section{METHODOLOGY}

\section{Research Design}

This descriptive study aimed to examine perception towards E-learning quality dimensions, satisfaction with E-learning, behavioural intentions, and grade expectations of nursing students. The researcher recruited the participants through convenient sampling from one of the private healthcare universities in Negeri Sembilan state. Junior or senior undergraduate nursing students at all levels were involved in the study. The data collection was done in June 2020 for over two weeks.

\section{Participants}

The sample size was calculated using the Krecjie Morgan table (Krejcie \& Morgan, 1970). Based on the population size and using the Krejcie-Morgan table, a total of 210 samples were required for the survey. The respondents of the study were nursing students from the undergraduate nursing program who have already had classes as E-learning during the COVID-19 pandemic. A total of 160 nursing students (response rate of $76 \%$ ) responded to this online cross-sectional survey using Google forms. The majority of the respondents were females (92\%) Malays (81\%) from the Diploma in nursing program $(90 \%)$ with a mean age of 21.5 years $(\mathrm{SD}=2.2)$. All the 160 responses were included in this study, as the data had no missing data.

\section{Data Collection Tool}

The SERVQUAL questionnaire is a validated questionnaire (Udo, Bagchi \& Kirs, 2011). The permission to use the questionnaire was obtained from the researcher who developed the questionnaire. The SERVQUAL tool has 35 questions, and only 34 items were included in this study. The quality dimensions has five (5) constructs with 22 items. The five constructs are "Empathy" (4 items), "Assurance" (4 items), "Responsiveness" (3 items), "Reliability" (3 items), and Web content (8 items). Questions on E-learning quality comprises of 4 items. Satisfaction with E-learning and behaviour intentions has 4 and 3 items, respectively. Grade expectations consist of two (2) items. However, only one item was included in this study. The item on "what grade you expect from this class" was not included in this study. Besides, the questionnaire also assessed the general characteristics of the respondents'. 


\section{Data Collection Procedure}

The Research Management Centre approved the study on $1^{\text {st }}$ June 2020 . Online permission was obtained from the respondents using a separate section in Google forms before collecting the data of this study. The respondents of this study were communicated using the Email addresses registered with the University Learning Management System and Google forms had been shared. The respondents were allowed to respond as per their convenience.

The scoring of the data was prepared as follows. Responses were made on a 4-point Likert scale ranging from 1 point for "strongly disagree to 4 points for strongly agree. Higher scores indicated better E-learning quality. The 4-point Likert scale was further dichotomized for data interpretation purposes (Strongly agree $\&$ agree $=$ Positive agreement; Disagree and strongly disagree $=$ Negative agreement). Two items on behavioural intentions "Would you recommend this e-learning to someone else?" and "Would you report any problems you find while you are still enrolled in the program?" and one item regarding satisfaction with E-learning "Would you agree to say that "I am satisfied with my opportunities to enrol in online classes?" was scored using the dichotomous scale. The overall "Reliability" of the SEVQUAL questionnaire in the main survey was Cronbach's $\infty=0.923$.

\section{DataAnalysis}

The collected data were analysed using the SPSS 26.0 version, and the main variables were normally distributed according to the Kolmogorov-Smirnov test. All the 34 items were analysed using frequency, percentage, mean and standard deviation. The "Reliability" of the questionnaires was calculated using Cronbach's $\infty$. The association between the different constructs in the study was determined using the Pearson correlation coefficient.

\section{RESULTS}

\section{Demographic Profile of the Respondents}

Table 1 shows the demographic profile characteristics of the respondents. The majority of the respondents (92\%) were females aged 20-25 years and were Malays $(82 \%)$. Ninety percent of students were from the Diploma in nursing programs undergoing year 2 of the training $(57 \%)$.
Table 1: Demographic Characteristics of Sample Nursing Student Respondents

\begin{tabular}{|c|c|c|c|}
\hline Variables & Characteristics & $\begin{array}{c}\text { Frequency } \\
\text { (N) }\end{array}$ & $\begin{array}{c}\text { Valid Percent } \\
(\%)\end{array}$ \\
\hline \multirow[t]{3}{*}{ Age } & $<20$ years & 83 & 52 \\
\hline & 20-25 years & 61 & 38 \\
\hline & $>25$ years & 16 & 10 \\
\hline \multirow[t]{2}{*}{ Gender } & Female & 147 & 92 \\
\hline & Male & 13 & 8 \\
\hline \multirow[t]{4}{*}{ Ethnicity } & Malay & 130 & 81 \\
\hline & Chinese & 13 & 8 \\
\hline & Indian & 13 & 8 \\
\hline & Others & 4 & 3 \\
\hline \multirow{2}{*}{$\begin{array}{l}\text { Type of } \\
\text { Program }\end{array}$} & Diploma & 144 & 90 \\
\hline & Bachelor & 16 & 10 \\
\hline \multirow{3}{*}{$\begin{array}{l}\text { Level of } \\
\text { program }\end{array}$} & Year 1 & 19 & 12 \\
\hline & Year2 & 91 & 57 \\
\hline & Year 3 & 50 & 31 \\
\hline \multirow{5}{*}{$\begin{array}{l}\text { Monthly } \\
\text { income of } \\
\text { family }\end{array}$} & $<1000$ & 37 & 23 \\
\hline & $1001-5000$ & 91 & 57 \\
\hline & $5001-10000$ & 23 & 14 \\
\hline & $10001-15000$ & 7 & 4 \\
\hline & $>15000$ & 1 & 0.6 \\
\hline
\end{tabular}

\section{Perception of E-learning Quality Dimensions}

Table 1 shows that all the five (5) constructs had a positive agreement on a 4-point Likert scale from strongly disagree to strongly agree. The construct on "Empathy" was rated to have positive quality experience (M=12.24/16; $\mathrm{SD}=1.4)$. "'Assurance" of the lecturer also had a high positive agreement level $(\mathrm{M}=$ $12.71 / 16$; $\mathrm{SD}=1.5$ ). Quality of experience towards the "'Responsiveness"' of lecturers also had been highly in agreement with a positive rating $(\mathrm{M}=9.41 / 12 ; \mathrm{SD}=$ $1.29)$ and "Reliability" $(\mathrm{M}=9.29 / 12, \mathrm{SD}=1.27)$. 'Web content' had a comparatively low mean score among the five (5) quality dimensions ( $\mathrm{M}=24.1 / 32 ; \mathrm{SD}=2.82)$.

Table 1: Overall Perception of E-learning Quality Dimensions $(N=160)$

\begin{tabular}{|l|c|c|c|c|c|c|}
\hline & Minimum & Maximum & $\begin{array}{c}\text { Mean } \\
(\mathbf{M})\end{array}$ & $\begin{array}{c}\text { Std. } \\
\text { Deviation } \\
\text { (SD) }\end{array}$ & $\begin{array}{c}\text { Std. } \\
\text { Error } \\
\text { (SE) }\end{array}$ & $\begin{array}{c}\text { Reliability } \\
\text { (Cronbach } \\
\text { alpha) }\end{array}$ \\
\hline Empathy & 8.00 & 16.00 & 12.24 & 1.4 & 0.11 & 0.766 \\
\hline Assurance & 8.00 & 16.00 & 12.71 & 1.5 & 0.12 & 0.813 \\
\hline Responsiveness & 6.00 & 12.00 & 9.41 & 1.29 & 0.11 & 0.676 \\
\hline Reliable & 5.00 & 12.00 & 9.29 & 1.27 & 0.1 & 0.781 \\
\hline Webcontent & 15.00 & 32.00 & 24.1 & 2.82 & 0.22 & 0.913 \\
\hline
\end{tabular}

As observed in Table 2, all the items had a positive agreement from the respondents in determining the 
quality of experience with E-learning. Regarding "Empathy," the item which had the highest positive rating $(98 \%)$ was "the Lecturers encourages and motivates the students to do their best" (Q4, 3.2/4). The item "the Lecturers understand the individual needs of students" had the lowest positive rating with $87 \%$ rating positively (Q2, 2.9/4). As observed in Table 3, the other three constructs on "Assurance," "Responsiveness," and "Reliability" also was rated all the items positively.
The construct of 'Web content' referred to the quality of the resources provides by the lecturers in meeting the learning objectives of the students. This section had eight (8) items. "The web site provides useful information" was the most highly positively rated item in this category (96\%). The item on "the web site provides high-quality information" had been rated relatively low, with $88 \%$ of the respondent rating positively.

Table 2: Perception of E-learning Quality Dimensions

\begin{tabular}{|c|c|c|c|c|c|c|c|}
\hline & \multirow[t]{2}{*}{ Items } & \multicolumn{2}{|c|}{ Strongly agree/agree } & \multicolumn{2}{|c|}{$\begin{array}{l}\text { Disagree/Strongly } \\
\text { disagree }\end{array}$} & \multirow[t]{2}{*}{ Mean } & \multirow[t]{2}{*}{ SD } \\
\hline & & $f$ & $\%$ & $f$ & $\%$ & & \\
\hline & \multicolumn{7}{|l|}{ Lecturers' attributes } \\
\hline & "Empathy" & & & & & & \\
\hline 1 & The Lecturers are genuinely concerned about the students. & 152 & 95 & 8 & 5 & 3.1 & 0.47 \\
\hline 2 & The Lecturers understand the individual needs of students & 139 & 87 & 21 & 13 & 2.9 & 0.49 \\
\hline 3 & $\begin{array}{l}\text { The Lecturers has the students' best long-term interest in } \\
\text { mind }\end{array}$ & 145 & 91 & 15 & 9 & 3 & 0.40 \\
\hline \multirow[t]{2}{*}{4} & $\begin{array}{l}\text { The Lecturers encourages and motivates the students to } \\
\text { do their best }\end{array}$ & 157 & 98 & 3 & 2 & 3.2 & 0.45 \\
\hline & "Assurance" & & & & & & \\
\hline 5 & The Lecturers is knowledgeable in his/her field. & 156 & 98 & 4 & 2 & 3.3 & 0.49 \\
\hline 6 & The Lecturers is fair and impartial in grading & 156 & 97 & 3 & 3 & 3.1 & 0.37 \\
\hline 7 & The Lecturers answers all questions thoroughly & 154 & 97 & 5 & 3 & 3.2 & 0.49 \\
\hline \multirow[t]{2}{*}{8} & $\begin{array}{l}\text { I am confident the Lecturers has an expert understanding } \\
\text { of the material }\end{array}$ & 153 & 96 & 6 & 4 & 3.2 & 0.52 \\
\hline & "Responsiveness" & & & & & & \\
\hline 9 & $\begin{array}{l}\text { The Lecturers quickly and efficiently respond to students' } \\
\text { needs. }\end{array}$ & 148 & 93 & 11 & 7 & 3.7 & 0.49 \\
\hline 10 & $\begin{array}{l}\text { The Lecturers are willing to go out of his/her way to help } \\
\text { students }\end{array}$ & 144 & 90 & 6 & 10 & 3.0 & 0.67 \\
\hline \multirow[t]{2}{*}{11} & $\begin{array}{l}\text { The Lecturers always welcomes students' questions and } \\
\text { comments }\end{array}$ & 160 & 100 & - & - & 3.3 & 0.46 \\
\hline & "Reliability" & & & & & & \\
\hline 12 & The Lecturers consistently provides good online lectures. & 143 & 89 & 15 & 11 & 3.0 & 0.56 \\
\hline 13 & The Lecturers are dependable. & 145 & 91 & 14 & 9 & 3.0 & 0.51 \\
\hline \multirow[t]{2}{*}{14} & The Lecturers reliably corrects information when needed. & 157 & 98 & 3 & 2 & 3.2 & 0.43 \\
\hline & Web content in the Learning Management System & & & & & & \\
\hline 15 & The web site uses audio elements properly. & 142 & 90 & 16 & 10 & 2.9 & 0.5 \\
\hline 16 & The web site uses video elements properly. & 142 & 90 & 16 & 10 & 3 & 0.5 \\
\hline 17 & The web site uses multimedia features properly. & 147 & 92 & 13 & 8 & 3 & 0.4 \\
\hline 18 & The web site uses animations/graphics properly. & 144 & 90 & 16 & 10 & 3 & 0.5 \\
\hline 19 & The web site provides useful information. & 153 & 96 & 7 & 4 & 3 & 0.4 \\
\hline 20 & The web site provides accurate information & 151 & 84 & 9 & 6 & 3 & 0.4 \\
\hline 21 & The web site provides high-quality information. & 141 & 88 & 19 & 12 & 2.9 & 0.5 \\
\hline 22 & The information on the web site is relevant to me. & 145 & 91 & 15 & 9 & 2.9 & 0.4 \\
\hline
\end{tabular}




\section{E-learning Quality}

Table 3 shows the three items were on a 4- point Likert scale. 'The instructional web site seems to be up to date' had the highest positive rating (92\%). "The instructional web site works well" had the lowest agreement with $85 \%$ rating their experience as a positive one.

\section{Table 3: E-learning Quality}

\begin{tabular}{|c|l|c|c|c|c|c|c|}
\hline \multirow{2}{*}{} & Items & \multicolumn{2}{|c|}{$\begin{array}{c}\text { Strongly } \\
\text { agree/agree }\end{array}$} & \multicolumn{2}{|c|}{$\begin{array}{c}\text { Disagree/Stro } \\
\text { ngly disagree }\end{array}$} & Mean & SD \\
\cline { 2 - 6 } & $\boldsymbol{f}$ & $\%$ & $\boldsymbol{f}$ & $\%$ & & \\
\hline 1 & $\begin{array}{l}\text { The } \\
\text { instructional } \\
\text { web site seems } \\
\text { to be up to date. }\end{array}$ & 146 & 92 & 14 & 8 & 3 & 0.4 \\
\hline 2 & $\begin{array}{l}\text { The } \\
\text { instructional } \\
\text { web site works } \\
\text { well. }\end{array}$ & 136 & 85 & 24 & 15 & 2.9 & 0.5 \\
\hline 3 & $\begin{array}{l}\text { The } \\
\text { instructional } \\
\text { web site has } \\
\text { clear } \\
\text { instructions }\end{array}$ & 139 & 87 & 21 & 13 & 2.9 & 0.5 \\
\hline
\end{tabular}

The construct E-learning quality had four (4) items. Table 3 shows that three items were on a 4- point Likert scale. 'The instructional web site seems to be up to date' had the highest positive rating (92\%). "The instructional web site works well" had the lowest agreement with $85 \%$ rating their experience as a positive one. "Your perception of the overall quality of the instruction you get from E-learning" was rated on a 5-point rating scale with $5=$ excellent and $1=$ poor. The majority $(50 \%)$ rated the perception of the overall quality of E-learning experience as average. Twenty-nine percentage rated as good and $3 \%$ rated as excellent.

\section{Behavioral Intentions}

The behavioural intentions to continue with the Elearning for the future was assessed using three questions. Two questions were on a dichotomous scale of definitely would or definitely would not. For the question "Would you recommend this E-learning to someone else?" $62 \%(\mathrm{n}=98)$ agreed that they would recommend to others. For the next item, had a positive rating by $81 \%(n=130)$ of the respondents. "Would you report any problems you find while you are still enrolled in the program?
The third question was evaluated using 4 points Likert scale as "I know I get good value for the fee I paid for e-learning" had a very low agreement $(\mathrm{M}=2.5 / 4$, $\mathrm{SD}=0.8$ ).

\section{Satisfaction with E-learning}

As presented in Table 4, there was a total of three (3) items for the scale to measure satisfaction with Elearning. These three (3) items were collected using a 4-point Likert range. The rating had a borderline majority. The highest positive response was for the item "would you agree to say that "I think I did the right thing when I enrolled for E-learning classes," with 59\% respondents rated positively. An additional item on a dichotomous scale, "Would you agree to say that I am satisfied with my opportunities to enroll in online classes?" showed the majority (56\%) responded positively to satisfaction with E-learning.

Table 4: Satisfaction with E-learning

\begin{tabular}{|c|l|r|r|r|r|l|l|}
\hline Items & \multicolumn{2}{|c|}{$\begin{array}{c}\text { Strongly } \\
\text { agree/agree }\end{array}$} & \multicolumn{2}{|c|}{$\begin{array}{c}\text { Disagree/Stron } \\
\text { gly disagree }\end{array}$} & \multirow{2}{*}{ Mean } & SD \\
\cline { 2 - 6 } 1 & $f$ & $\%$ & $f$ & $\%$ & & \\
\hline 1 & $\begin{array}{l}\text { Would you agree to } \\
\text { say that "My choice to } \\
\text { enrol in online classes } \\
\text { was a wise one?" }\end{array}$ & 89 & 56 & 71 & 44 & 2.5 & 0.76 \\
\hline 2 & $\begin{array}{l}\text { Would you agree to } \\
\text { say that "I think I did } \\
\text { the right thing when I } \\
\text { enrolled for E-learning } \\
\text { classes?" }\end{array}$ & 94 & 59 & 66 & 41 & 2.5 & 0.8 \\
\hline 3 & $\begin{array}{l}\text { Would you agree to } \\
\text { say that "I feel that my } \\
\text { experience with E- } \\
\text { learning has been } \\
\text { enjoyable?" }\end{array}$ & 92 & 58 & 68 & 42 & 2.5 & 0.79 \\
\hline
\end{tabular}

\section{Grade Expectations}

The item was "I expect to do very well (I did very well) in this online class" had a very low margin of positive rating by the nursing students $(\mathrm{M}=2.5 / 4$, SD $=0.77$ ).

\section{Correlation Studies}

A Pearson product-moment correlation coefficient was computed to assess the relationship between Elearning quality and five quality domains of the SERVQUALquestionnaire. 
Table 5: Relationship between E-Learning Quality with Different Quality Dimensions ( $N=160)$

\begin{tabular}{|l|c|c|}
\hline Variables & $\begin{array}{c}\text { Pearson Correlation } \\
\text { (r) }\end{array}$ & $\begin{array}{c}\text { Sig. (2-tailed) } \\
\text { (p-value) }\end{array}$ \\
\hline Empathy & 0.468 & 0.000 \\
\hline Assurance & 0.427 & 0.000 \\
\hline Responsiveness & 0.489 & 0.000 \\
\hline Reliability & 0.733 & 0.000 \\
\hline Web content & 0.733 & 0.000 \\
\hline Satisfaction with E-learning & 0.462 & 0.000 \\
\hline Behavioural intentions & 0.185 & 0.019 \\
\hline Grade expectations & 0.401 & 0.000 \\
\hline${ }^{* *}$ Correlation is significant at the 0.01 level (2-tailed).
\end{tabular}

The constructs "Empathy," "Assurance," and "Responsiveness" had moderate Correlation with Elearning quality. Increases in E-learning quality were correlated with improvements in scores for "Empathy," "Assurance," and "Responsiveness." "Reliability" and web content had a high positive Correlation with Elearning quality.

A Pearson correlation coefficient study shows that grade expectations of the students had positive Correlation with satisfaction towards E-learning $(r=0.717 ; p=0.000)$ correlation is significant at the 0.01 level (2-tailed). Another Pearson correlation coefficient to identify the relationship between web content quality and satisfaction with E-learning $(r=0.469 ; p=0.000)$.

\section{DISCUSSION}

The private healthcare University is committed to the robust implementation of E-learning, including Eassessment much before the COVID-19 pandemic. Guidance and training in the use of Moodle as a virtual learning environment are regularly provided to all staff, including the process to conduct Moodle online examinations. The Moodle is managed by the "Centre for Innovation in Teaching and Education" (CITE). However, during the COVID-19 pandemic, all teachinglearning activities were shifted to E-learning. Deserting students' needs and expectations and disregarding competitive forces in higher education fields eventually leads to becoming the most distinct weaknesses of a higher education institution (Mestrovic, 2017). This study was aimed to determine nursing students' quality of experience, satisfaction, behavioural intentions, and grade expectations in keeping with the E-learning during the COVID 19 pandemic.

The four attributes of lecturers like "Empathy,"
"Assurance," "Responsiveness," and "Reliability" had been rated positively by students, which shows that teachers put in a great effort in ensuring students are comfortable with E-learning. Even though the lecturers, were new to providing $100 \%$ E-learning, have demonstrated commitment in delivering the best they could during the COIVD 19 pandemic. Web content quality refers to layout and presentation along with layout of information on the website. The dimensions of web site content quality also involve quality and appropriateness of the information, types of media used to present the resources, use of images and appropriateness of overall content, and relevance of the materials to the course (Udo, Bagchi \& Kirs, 2011). As mentioned by, systems and information quality have a positive relationship with students' satisfaction with Elearning (Kutlu \& Alkaya, 2015). Udo, Bagchi \& Kirs, (2011) in their study, also highlighted that user satisfaction is related to web content quality. This study also stressed that "Empathy" and "Assurance" of the Elearning instructors are positively related to E-learning quality In the same study, the "Responsiveness" was not significant, but "Reliability" "was partially significant with the E-learning quality and satisfaction of the students (Stodnick \& Rodger, 2008). However, in this present study, both "Reliability" and "Responsiveness" of the instructors' were important determinates of Elearning quality and satisfaction. The findings suggested that the commitment of the lecturers in implementing the E-learning platform for teaching and learning during the COVID 19 pandemic. In a similar study it was showed that instructors' attitudes toward Elearning, course quality, and perceived usefulness of the E-learning platform are the vital factors affecting learners' satisfaction with E-learning (Sun et al., 2008).

Similar studies using SERVQUAL have reported positive Correlation between customer satisfaction and four quality dimensions namely "Empathy," "Responsiveness," "Assurance" and "Reliability" (Qin \& Prybutok, 2009)

In this study, nursing students have a partial agreement with web content provided in the LMS. As study reported that the E-learning service quality provided by the Higher education organization is determined by E-learning system quality, E-learning instructor, and course materials quality, E-learning administrative and support service quality (Pham et al., 2019). The sudden shift from traditional classroom teaching and learning to E-learning was very new to the 
academicians, and not all lecturers are Information and Communication Technology Savvy. This would have affected the web content quality as perceived by the students.

The study findings are in agreement with another qualitative study, which reported that the E-learning service quality provided by the Higher education organization is determined by E-learning system quality, E-learning instructor and course materials quality, and E-learning administrative and support service quality (Gohiya \& Gohiya, 2020). Consistent with the findings of the study, in a similar study, the students rated online instruction as moderately satisfactory (Cole, Shelley \& Swartz, 2014).

The study findings also revealed that satisfaction and behavioural intentions in continuing E-learning was related to E-learning quality. These findings agree with the results of another study in which E-learning quality is a mediating factor in determining the behavioural intentions towards E-learning (Pham et al., 2019). In this study, "Grade expectation" was established to have a stronger positive relationship with E learners' satisfaction with the E-learning experience. This finding confirms the findings of in which grade expectations were in alignment with the satisfaction of students with E-learning (Eiszler, 2002).

\section{Limitations}

One weakness of this study could be the use of students from one university. However, the students came from different backgrounds and cultures and were enrolled in both Diploma and Bachelor of Nursing programs online.

\section{RECOMMENDATIONS}

In case of Higher, Education providers, satisfaction is a vital factor in sustaining and enlightening competitive advantage in today's highly modest Elearning environment. Higher Education institutions with online programs need to develop strategies that focus on the dimensions of e-learning quality that augments E-learners' satisfaction, which in turn can lead to positive and unrelenting behavioural intentions. Unpretentiously stated, satisfied E-learners are more likely to be loyal customers, those will continue to enrol in online programs, and endorse the program to others.

\section{CONCLUSION}

This paper describes an assessment of the Elearning experience of nursing students during the COVID 19 pandemic. The results were very encouraging, and a large percentage of students were engaged with the process of E-learning. It was found that the students generally had a positive perception of E-learning. The quality of perceived by the E-learning also had positive Correlation with the four dimensions of the SERVQUAL scale measuring the quality of experience with E-learning instructors'. Nursing students were found to be in favour of the E-learning provided the web content quality is good. The findings also revealed that the grade expectations of the students were directly proportional to the satisfaction with the E-learning experience.

\section{Conflict of Interests}

The authors declare that they have no conflict of interest.

\section{ACKNOWLEDGMENTS}

The authors' are thankful to KPJ Healthcare University College (KPJUC) management for supporting this research.

\section{REFERENCE}

Aggarwal, A. \& Comyn, P. F. P. (2020). Discussion: Continuing online learning and skills development in times of the COVID-19 crisis. Retrieved from: https://www.skillsforemployment.org/KSP/en/Discussions/EDMSP1 256625

Cole, M.T., Shelley, D. J. \& Swartz, L. B. (2014). Online instruction, e-learning, and student satisfaction: A three-year study. International Review of Research in Open and Distance Learning, 15(6), pp 111-131.

Doherty, W. (2006). An analysis of multiple factors affecting retention in web-based community college courses. The Internet and Higher Education, 9(4), pp 245-255.

Eiszler, C.F. (2002). College students' evaluations of teaching and grade inflation. Research in Higher Education, 43(4), pp 483-501. 
Gohiya, P. \& Gohiya, A. (2020). E-learning during COVID 19 Pandemic. Research Square, pp 4-9. Retrieved from: https://www.researchsquare.com/article/rs-29575/v1.

Krejcie, R. V. \& Morgan, D. W. (1970). Table for determining sample size from a given population. Educational and Psychological Measurement, 30(3), pp 607-610.

Kutlu, B. \& Alkaya, A. (2015). Measuring the Delone and Mclean Model of Information Systems Success Applied to Banking Sector of Turkey. International Journal of Advanced Computational Engineering and Networking, 3(8), pp 2320-2106.

Mestrovic, D. (2017). Service Quality, Students' Satisfaction and Behavioural Intentions in STEM and IC Higher Education Institutions. Interdisciplinary Description of Complex Systems, 15(1), pp 66-77. doi: 10.7906/ indecs.15.1.5.

Pham, L., Limbu, Y.B., Bui, T.K., Nguyen, H.T. \& Pham, H.T. (2019). Does e-learning service quality influence elearning student satisfaction and loyalty? Evidence from Vietnam. International Journal of Educational Technology in Higher Education. 16(1), 7.

Qin, H. \& Prybutok, V.R. (2009). Service quality, customer satisfaction, and behavioral intentions in fast-food restaurants. International Journal of Quality and Service Sciences, 1(1), pp 78-95.

Stodnick, M. \& Rodger, P. (2008). Using SERVQUAL to measure the quality of the classroom experience. Decision Sciences Journal of Innovative Education, 6(1), pp 115-133.

Sun, P.C., Tsai, R.J., Finger, G., Chen, Y.Y. \& Yeh, D. (2008). What drives a successful e-Learning? An empirical investigation of the critical factors influencing learner satisfaction. Computers and Education, 50(4), pp $1183-1202$.

Udo, G. J., Bagchi, K. K. \& Kirs, P. J. (2011). Using SERVQUAL to assess the quality of e-learning experience. Computers in Human Behavior. Elsevier Ltd, 27(3), pp 1272-1283. 